\title{
COL. EDWARD HATCH'S GREAT CHARGE AT FARMINGTON, MISSISSIPPI.
}

BY COL. CHARLES C. HORTON,*

The cavalry division of the Army of the Mississippi, commanded by Gen. Gordon Granger, was composed of two brigades of two regiments each. The first brigade consisting of the 3rd Michigan and the 7th Illinois Cavalry, was commanded by Col. J. K. Mizner.

The 2nd Iowa and the 2nd Michigan Cavalry formed the second brigade, commanded by Col. W. L. Elliott. (It was while commanding the second brigade that Gen. Phil Sheridan won his first star.)

The Division returning from near Fort Pillow landed at Hamburg, Tenn., on the 23rd of April, 1862, and under Gen. John Pope was assigned to duty on the left wing of Gen. Halleck's army in his very cautious advance on Corinth. The Division was kept constantly on the scout over a strip of country some twenty miles in width lying between. the Memphis and Charleston railroad on the south and the Monterey and Hamburg road on the north. Between Gen. Pope's camp and Farmington there was a stream and an impassable swamp crossed by a corduroy road and bridge.

On the 8th of May, 1862, Gen. E. A. Paine crossed the swamp and after a sharp skirmish took a position on the heights of Farmington. During the night following, Gen. Price moved his command around Paine's left flank with the evident intention of cutting off his retreat, but either the march was too long, or Gen. Van Dorn made his front attack too soon, at all events his attempt was happily a failure.

* Col. Horton was the second lieutenant of Co. A, Second Iowa Cavalry. He participated in the charge at Farmington, where he had a horse killed under him. He writes therefore from the standpoint of an eye-witness. He was commended for gallantry by Col. Waslington $L$. Elliott, who was then in command of the regiment. Col. Horton is now commandant at the Soldiers' Home, at Marshalltown, Iowa. 
During the morning the roar of cannon came to us from towards Corinth with an ominous sound, and at 10 a. m. an orderly dashed into camp with orders for Col. Hatch to fly with all possible haste and report to Gen. Paine at Farming ton. The bugle sounded, "Boots and saddles!" "To horse!" "Forward!" and in five minutes after the receipt of orders we were galloping to the front.

As we reached the open field, after crossing the swamp, we saw Gen. Paine's command stubbornly falling back from the hill, and the Rebel artillery dashing into position on the heights of Farmington, with twenty-four guns, from which position they could sweep the retreating lines with a murderous fre of grape and canister, shot and shell, as well as command the single road crossing the swamp and stream, and thus render the capture or annihilation of Paine's command almost certain. The regiment had been halted under cover of a small hill some twelve hundred yards from the Rebel batteries; between us was a plowed field across which ran a washout from two to eight feet wide, and of about the same depth.

The batteries must be silenced or all was lost; a sacrifice must be made to save the day; and the pale but resolute faces of the cavalry boys gave evidence that they realized the situation, and were ready to do their duty.

At this moment Gen. Paine dashed up to Col. Hatch, and in tones loud enough for the regiment to hear, gave the order to charge, take and hold the batteries. "Attention!" "Draw saber!" "Forward by battalion in echelon!" rang out the orders from Col. Hatch. Bugler Williamson sounded, "Forward!" "Trot!" "March!" and when clear of the infantry, the piercing notes of the "charge" rang out clear and shrill. Sabers flashed in the sunlight, spurs were driven cruelly into the flanks of maddened steeds, and leaning forward in their saddles with a wild, defiant yell the charge was on; over or into the ditch, up the hill, up to the guns, gunners cut down or driven back; but a supporting line 
fully fifteen thousand strong checked the mad charge and drove us back.

Though repulsed and driven back, victory rested upon our colors, for all and more than could be hoped for had been achieved. The guns were trained upon the charging columns, and Paine thus permitted to hastily, but in an orderly manner, conduct his retreat in safety; and ere the Rebel gunners had effectively remanned their guns, the gallant second had, though torn and bleeding, recrossed the swamp.

The charge lasted not over five minutes, but we lost fifty men, killed and wounded, and over one hundred horses left upon the field. The wounded were nearly all picked up by the retiring line and carried back to the hospital by their devoted and courageous comrades.

This small loss can only be accounted for by the great clouds of dust, raised by the horses as we crossed the field, the wild shouts of the charging column taken up by Paine's command, and answered by the command across the swamp; all this with the very audacity of the charge probably deceived the Rebels as to our numbers. At first their gunners fired too high, and then too low.

After the charge Col. Elliutt took Gen. Paine to task for giving such an emphatic order. Gen. Paine excused himself by saying, "I did not think they would go so far," to which the gallant Colonel responded, "That is my regiment and they will charge Hell if ordered, but I did not expect to have them ordered there."

In my opinion Gen. Paine did the right thing, as it was better to sacrifice a regiment than to lose his division. 
Copyright of Annals of Iowa is the property of State of Iowa, by \& through the State Historical Society of Iowa and its content may not be copied or emailed to multiple sites or posted to a listserv without the copyright holder's express written permission. However, users may print, download, or email articles for individual use. 